\title{
Bikers, Aliens, And Movie Stars: Comparing The Economic Impact Of Special Events
}

Neil Terry, West Texas A\&M University, USA

Anne Macy, West Texas A\&M University, USA

James K. Owens, West Texas A\&M University, USA

\begin{abstract}
This paper compares the economic impact of the Sturgis Motorcycle Rally, Roswell UFO Festival, and the Sundance Film Festival in Park City. The three cities and special events are evaluated based on information relating to population, income, home valuation, event estimates for number of visitors and expenditures, and city sales tax information. Park City is the leader in population growth, household income growth, and median home value growth for the years 2000-2007. In fact, population growth for Roswell and Sturgis is on the decline despite rising median household income and home valuations. Participation and dollar value of the event is clearly dominated by the Sturgis Motorcycle Rally (420,000 annual participants generating $\$ 130$ million in expenditures), followed by the Sundance Film Festival (39,000 annual participants generating $\$ 60$ million in expenditures), and the Roswell UFO Festival (10,000 annual participants generating $\$ 1.25$ million). The results of this study clearly imply the Sturgis Motorcycle Rally is integral to the economic healthy of the region, the Sundance Film Festival is an important and growing special event for the U.S. film industry, and the Roswell UFO Festival helps the city maintain a unique identity that might not otherwise exist.
\end{abstract}

Keywords: Economic Impact, Park City, Regional Development, Roswell UFO Festival, Sturgis Motorcycle Rally, Sundance Film Festival, Tourism

\section{INTRODUCTION}

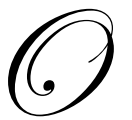

$\mathrm{n}$ almost any day, somewhere in the world there is a special event or festival. Festivals and special events play a significant role in several communities because they provide important activities and spending outlets for locals and visitors and enhance the local community image (Getz, 1997; Thrane, 2002). Three high-profile, regional special events are the Sturgis Motorcycle Rally, Roswell UFO Festival, and the Sundance Film Festival. The purpose of this paper is to offer a discussion of the comparative economic impact of the Park City, Roswell, and Sturgis special events. This manuscript is organized as follows: First, a brief review of the related literature is presented. Second, an overview of Park City, Utah and the Sundance Film Festival is provided. The third section offers an overview of Roswell, New Mexico and the UFO Festival. The next section provides an overview of Sturgis, South Dakota and the Motorcycle Rally. The fifth section compares the economic impact of the three special events. The final section offers conclusions.

\section{LITERATURE REVIEW}

Festivals and special events are one of the fastest growing types of tourism attractions (Crompton \& McKay, 1997). Therefore, it is not surprising to see that the number of conceptual and empirical studies on festivals and special events has increased in recent years. Most of the studies have focused on either the economic impact of festivals and special events (Thrane, 2002; Walo, Bull, \& Green, 1996; Uysal \& Gitelson, 1994) or the reasons and motivations of people to attend festivals and special events (Formica \& Murrmann, 1998; Nicholson \& Pearce, 
2001; Scott, 1996). Only a few studies offer a comparison of multiple festivals and special events (Madrigal, 1993; Tosun, 2002).

Several studies indicate the most important reason for organizing a festival or special event is the positive economic impact the activities have on the host communities (Crompton \& McKay, 1997; Thrane, 2002; Walo, Bull, \& Green, 1996; Uysal \& Gitelson, 1994). However, sociology literature suggests that the primary reason for collective celebrations is to build social cohesion by reinforcing ties within the community (Rao, 2001). Sociologists argue that festivals are generally connected with culturally-shared events. Festivals demonstrate what a society believes to be essential aspects of life and reinforce cultural identity by building strong ties within a community (Gursoy, Kim, \& Uysal, 2004). This suggestion is consistent with studies of residents' attitudes toward tourism development. They suggest that tourism increases pride and creates cultural identity, cohesion, and an opportunity to exchange ideas (Besculides, Lee, \& McCormic, 2002). Rao (2001) suggests that festivals also have public goods aspect that go beyond pure entertainment and revenue generation because they provide a specific time and place where families can show their commitment to the collective.

Chwe (1998) suggests that public events like festivals and special events also play an important role in creating a general common knowledge by providing a communication mechanism for residents to communicate social information. Festivals or special events provide incentives for the local community to reinforce ties within a community by generating common knowledge and by building trust. Thus, festivals and special events are likely to build social cohesion and trust by reinforcing ties within a community. Festivals and special events also provide incentives for businesses to get involved in the community because they provide promotional opportunities for businesses (Gursoy, Kim, \& Uysal, 2004).

Evidence also suggests that festivals and special events generate costs such as increases in prices of goods and services, shopping congestion, traffic congestion, and parking problems (Jeong \& Faulkner, 1996). Residents perceive that increases in traffic congestion and in pressure on local services are two of the major problems created by tourism activities (Keogh, 1990). Resident support of tourism development declines as the negative social impact of tourism increases (Tosun, 2002). Gursoy, Kim, \& Uysal (2004) find festival and special event organizers do not perceive festivals as having high social costs to the local community.

\section{PARK CITY AND THE SUNDANCE FILM FESTIVAL}

Park City was established in 1870 as a mining town. Silver ore helped the mining community survive multiple booms and bust over the years. Skiing came to the city in the 1950s and over the next thirty years the city established three major ski resorts. The city is approximately 25 miles from Salt Lake City. Several of the ski and snowboarding events for the 2002 Winter Olympics took place at the Park City resorts. Today, the tourist population of Park City greatly exceeds the permanent resident population of the city throughout most of the year.

The film festival began as the Utah/U.S. Film Festival in Salt Lake City in 1978 in an effort to attract more filmmakers to Utah. Chaired by Robert Redford, the festival highlighted independent American-made films created outside of the Hollywood system. In addition, it allowed filmmakers to see the advantages of filming in Utah. In 1981, the festival moved to Park City, Utah and changed dates from September to January to offer the venue at a resort location during ski season in an effort to attract more attention from Hollywood. In 1985, the Sundance Institute took over management of the festival and changed the name to the Sundance Film Festival, which is a reference to a character in the Redford movie Butch Cassidy and the Sundance Kid.

The Sundance Film Festival is credited for serving as a showcase for numerous films and credited for launching the careers of many famous filmmakers. The list of includes Steven Soderbergh (Sex, Lies, and Videotapes, 1989), Robert Rodriguez (El Mariachi, 1992), Paul Thomas Anderson (Cigarettes \& Coffee, 1993), Kevin Smith (Clerks, 1994), Edward Burns (Brothers McMullen, 1995), James Wan (Saw, 2004), James Hess (Napolean Dynamite, 2004), and Jonathan Dayton \& Valerie Faris (Little Miss Sunshine, 2006). The Festival has changed over the decades from a low-profile venue for small-budget, independent filmmakers from outside Hollywood to a high-profile business and media venue where independent films can be purchased by major studios. Today, getting a film accepted for the Sundance Film Festival is not easy. Festival programmers received more than 
9,000 submissions for the 2009 ten-day festival and screened a total of 210 features and shorts (Barber, 2009). Repeat attendance at the Sundance Film Festival is strong given the features and shorts change every year.

\section{ROSWELL AND THE UFO FESTIVAL}

Roswell is located in southeastern New Mexico. In 1869 Roswell began to take shape with the arrival of Van C. Smith, a professional gambler. Smith filed his claim in the spring of 1871 and changed the settlement's name to honor his father, Roswell Smith. In 1877, Captain Joseph C. Lea and family bought out Smith and became the owners of most of the land in Roswell and the surrounding area. Many consider Captain Lea to be the true founder of Roswell. Under Lea's control and influence, Roswell began an era of stability and growth. In 1890, a vast artesian water supply was discovered beneath Roswell and ditches were dug to divert the water into vegetable fields. That same year the First National Bank was established. By 1891, the town of Roswell was incorporated. For the next few decades, Roswell continued growing as a regional business hub with a strong focus on local commodities. Roswell's Walker Air Force Base was a location of military importance from 1941 to 1967. Today, Roswell is the commercial center for a resource-based economy: petroleum production, ranching, dairying, and farming with corn, chilies, pecans, cotton, and alfalfa as main crops (Meehan, 2008).

Historically, tourism has been a challenge for Roswell. The New Mexico cities of Taos and Santa Fe built considerable tourist trades around their historic architecture, museums, artist colonies, pueblos, and outdoor activities. Additionally, those towns are nestled within the southern Rocky Mountains which provide a majestic backdrop to their sites. However, Roswell did have a cachet that the town did not recognize until 1996. Roswell is the world's UFO capital according to many UFO experts and science fiction fans across the globe (Meehan, 2008). Roswell is most popularly known for having its name attached to what is now called the 1947 Roswell UFO Incident. Although the alleged crash site was over seventy miles from Roswell, the investigation and debris recovery was handled by the local Roswell Army Field. Prior to the late 1970s, UFO experts considered the Roswell Incident debunked. By the late 1970s, alleged eyewitnesses from the Roswell base were telling their stories to UFO researchers. The 1980 publication of the Roswell Incident by Charles Berlitz and William Moore helped increase the publicity surrounding the alleged UFO crash. The Roswell stories of multiple crashes, crash survivors, alien autopsy, and proximity to Area 51 captured the interest of the commercial media. Television shows, talk radio, and the print media capitalized on the public interest in the prospect of alien visitors, which often elaborated on the Roswell incident. By the mid-1990s, the reputation of Roswell as a UFO location was firmly established.

The Roswell UFO Encounter Festival was established in 1996. The first festival attracted an estimated 1,000 out of town visitors, which gained the attention of the local business community and downtown area. To mark the Roswell Incident's $50^{\text {th }}$ anniversary, a second UFO festival was held in 1997 . The second festival and $50^{\text {th }}$ anniversary celebration attracted an estimated 48,000 attendees (Paradis, 2002). Today, the Roswell UFO Festival attracts approximately 10,000 participants each year and is one of several efforts employed to attract tourist to Roswell via an alien-themed marketing effort by the city and business community.

\section{STURGIS AND THE MOTORCYCLE RALLY}

Sturgis, South Dakota was founded in 1878 and named after Colonel Sturgis who commanded the local Fort Meade Cavalry Post. The $4^{\text {th }}, 7^{\text {th }}$ and $10^{\text {th }}$ cavalry were stationed at Fort Meade at various times to protect the development of new settlements in the Black Hills area of South Dakota. The population of Sturgis is approximately 6,500 people with less than 25,000 residents in Meade County, which covers more than 2 million acres (about 3500 square miles) of predominantly farming land. The average farm size is roughly 2,500 acres and the largest crops are wheat, cattle and calves. Sturgis refers to itself as the Key City to the Black Hills because it is located at a corner of Meade County and is the start of the valley entrance to the northern Black Hills, which came to prominence with the discovery of gold in the late 1800's.

The Sturgis Rally was begun in 1938 as the Black Hills Classic by Clarence Pappy Hoel who was a member of the local Jackpine Gypsies Motorcycle Club. The first rally consisted of a race on August 14, 1938 with nine participants and a small audience and continued as such every year except 1942 (due to gas rationing) until 1949 when Main Street in Sturgis was blocked off for a motorcycle show and awards ceremony. Since that time, the 
rally has grown from a three-day event in 1964, to a five-day event in 1965 to the current official seven-day format begun in 1975. Vendors began renting space from the city of Sturgis in 1974 and the demand continued to grow such that the city established a separate city department in 2002 to replace all the prior contract labor hired to promote and organize the Sturgis Motorcycle Rally. The $69^{\text {th }}$ annual Sturgis Motorcycle Rally will take place from August 3-9 2009 although informal events begin almost a week before the official rally start, which begins with the mayor's ride through downtown Sturgis.

In $2008,1,191$ vendors displayed with total sales of $\$ 13,235,951$ in Sturgis and surrounding communities with total tax collections of $\$ 891,739$ including state and municipal sales taxes and state tourism tax revenues. Current expectations are that 2009 will be equal to or slightly greater than 2008 in attendance and tax revenues. Plans are already being made for the $70^{\text {th }}$ anniversary year in 2010 when the attendance is expected to sharply increase due to attendees wanting to be a part of the anniversary date.

Incredible roads like Needles Highway, Iron Mountain Road, the Wildlife Loop and Spearfish Canyon take riders past amazing destinations such as Mount Rushmore National Memorial, Custer State Park, Crazy Horse Memorial, Bear Butte State Park, the Badlands and Devil's Tower National Monument. Highway 14A's big, wide turns pass through the infamous town of Deadwood and the mining town of Lead while the awe-inspiring Highway 385 meanders past towns like Hill City, Silver City and Custer, all contained in the Black Hills National Forest. Most bikers acknowledge the riding experience in the Black Hills during August is breathtaking and creates a desire for repeat attendance.

Additionally, the World Championship Custom Bike Builders show; the reality that Harley Davidson traditionally introduces their new models of motorcycles during Sturgis week and the numerous opportunities for concerts, tattoo parlors, famous drinking holes along with the accompanying wet T-Shirt contests and Pickle Licking Championships provide 24/7 entertainment of varying types. Sturgis has not only accepted but embraced the two weeks each year when the rally changes their town because it provides economic stability that would not otherwise exist for the remaining fifty weeks of the year.

\section{COMPARING THE ECONOMIC IMPACT}

Comparative economic data for Park City, Roswell, and Sturgis is presented in Table 1. The table includes information relating to population, income, home valuation, event estimates for number of visitors and expenditures, and city sales tax information. The first two rows in Table 1 put forth population data for the three cities. Although all three cities are under 50,000 people, Roswell is relatively large at 45,569 compared to less than 10,000 for both Park City and Sturgis. The population differential is somewhat balanced by the observation that Sturgis and Park City are within 25 miles of much larger cities (e.g., Rapid City and Salt Lake City), while Roswell is the largest city within a 150-mile radius. It is interesting to note that population growth from the years 2000-2007 is a strong 7.7\% for Park City versus a negative growth rate for both Roswell and Sturgis. It is possible the Sundance Film Festival has not only increased national recognition of Park City but also converted some visiting tourist into permanent residents. The 2002 Winter Olympics might also be a contributing factor to the growth of Park City. The Roswell UFO Festival and Sturgis Motorcycle Rally do not appear to create population growth.

Two other areas of comparison for the cities in this study are household income and home values. Median household income for Park City is relatively high at $\$ 82,550$, Sturgis is second at $\$ 34,689$, and Roswell is a close third at $\$ 32,205$. The growth rate in median household income is a robust $25.5 \%$ for Park City, $18.2 \%$ for Roswell, and $14.7 \%$ for Sturgis. Home valuation information mirrors the household income information. Once again, Park City leads the way in both absolute median home value $(\$ 680,237)$ and growth in median home valuation $(62.9 \%)$. Roswell and Sturgis are relatively close to each other in both median home values $(\$ 88,991$ and $\$ 104,564)$ and growth in median home valuations $(59.5 \%$ and $53.1 \%$ ). The anecdotal results imply all three cities have achieved healthy growth in household income and home valuations, with Park City leading the way on both accounts.

Information relating to number of event participants, dollar value of event, and average expenditure per visitor offers traditional economic impact information for the three special events. The Sturgis Motorcycle Rally dominates annual event participants at 420,000, the Sundance Film Festival in Park City has the second most 
participants at 49,000, and the Roswell UFO festival attracts approximately 10,000 participants. The dollar values of the three events are correlated with the number of participants. The Sturgis event generates approximately $\$ 132$ million per year, the Park City event generates approximately $\$ 60$ million, and the Roswell event is a modest $\$ 1.25$ million. Average expenditure per participant is $\$ 1,224$ for Park City, which easily outpaces the $\$ 314$ for the Sturgis Motorcycle Rally and the $\$ 125$ for the Roswell UFO Festival.

Table 1: Comparative City Data

\begin{tabular}{llll}
\hline Variable & Park City & Roswell & Sturgis \\
\hline Population $^{1}$ & 8,030 & 45,569 & 5,990 \\
Population Change $^{2}$ & $+7.7 \%$ & $-0.8 \%$ & $-4.9 \%$ \\
Median Household Income $^{1}$ & $\$ 82,550$ & $\$ 32,205$ & $\$ 34,689$ \\
Median Household Income Change $^{2}$ & $+25.5 \%$ & $+18.2 \%$ & $+14.7 \%$ \\
Median Home Value $^{1}$ & $\$ 680,237$ & $\$ 88,991$ & $\$ 104,564$ \\
Median Home Value Change $^{2}$ & $+62.9 \%$ & $+59.5 \%$ & $+53.1 \%$ \\
Estimated Annual Event Participants $_{\text {Estimated Dollar Value of Event per Year }}$ & 49,000 & 10,000 & 420,000 \\
Average Expenditure Per Participant & $\$ 60,000,000$ & $\$ 1,250,000$ & $\$ 132,000,000$ \\
Annual City Sales Tax Revenue & $\$ 1,224$ & $\$ 125$ & $\$ 314$ \\
Event Dollar Valued Divided by City Tax Revenue & $\$ 6,800,000$ & $\$ 17,500,000$ & $\$ 2,800,000$ \\
\hline
\end{tabular}

Notes: ${ }^{1}$ Estimated for the year 2007. ${ }^{2}$ Based on change between years 2000 to 2007.

Sources: City-data.com, interview with city government officials, and state sales tax data.

The attendance and economic figures merit further discussion. Clearly, the biggest of the three events is the Sturgis Motorcycle Rally. The Sturgis event offers an opportunity to explore numerous riding paths in a mountain setting near Mount Rushmore. The Black Hills location combined with the opportunity to socialize with a community of common interest peers make the Sturgis Motorcycle Rally a special event powerhouse. Many of the attractions in the Black Hills are free or have a low admission fee. For those bikers willing to camp, there are numerous campgrounds within the Hills. While not the most expensive of all hobbies, motorcycling requires some disposable income. A new Harley-Davidson motorcycle starts at $\$ 12,500$ and can easily cost over $\$ 20,000$ with customization and other features. For many riders, the bike is the expenditure and they look for inexpensive places to ride. This makes the Rally very affordable and encourages repeat attendance. Additionally, motorcycling has the stigma of rebellious behavior. For many motorcyclists, such as physicians, lawyers, small business owners, or other professionals who rely on reputation for their businesses, they do not want to alter their standing in their home community by wearing black leather, not shaving, and riding their motorcycle. The Rally provides a safe place to practice the hobby separate from daily life.

Repeat attendance is important to the continuity of the Rally and to its economic impact. Repeat attendees are more likely to venture further away from Sturgis to explore places such as Hot Springs and the Mammoth Digs in the southern Black Hills. Devil's Tower National Monument in eastern Wyoming has a jump in attendance each year coinciding with the Rally. Thus, the economic impact from the Rally is spread over a much larger area than just Sturgis and a key part of the impact is repeat attendees. Sturgis and the state of South Dakota recognize this and work to create an environment of repeat attendance. Road construction is halted in the Hills for this time period to ensure full availability of all roads. Various towns and businesses have specials and discounts for the bikers. In addition to the newest Harley-Davidson motorcycle being released at the Rally, world-class bands and comedians perform nightly at the legendary Buffalo Chip Campground. Starting in 1982 with just three bands, it has expanded to nine nights of concerts in 2009 with performers including Aerosmith and Toby Keith. Each ticket is for the concert and one night's camping to allow attendees to enjoy the party and not drink and drive. This is all done to ensure a successful Rally and encourage repeat attendance.

The relatively high expenditure per participant is the dominant economic impact category for the Sundance Film Festival in Park City. The fact that Park City is a resort location and the event is scheduled during peak ski season is one possible reason for the significant economic impact of the event. A second explanation for the high average expenditure per participant in Park City can be explained by the fact that the Sundance Film Festival is an opportunity to buy and sell independent films, in addition to being a film festival. For example, Little Miss Sunshine 
received several studio bids at the Sundance Film Festival. In fact, the film sold for $\$ 10.5$ million plus $10 \%$ of gross revenues within 24 hours of premiering at Sundance. The Sundance Film Festival continues to grow and expand as an important business component of the U.S. film industry.

While the retail businesses at Sturgis focus on T-shirts and tattoos, the retail businesses in Park City focus on a higher income level. Louis Vuitton, Tiffany's and Cartier are just some of the brands featured by the regular stores. Certain products are premiered during the film festival such as the Todd Oldham recycled backpack to the latest Lexus green vehicle. In addition, many stores open for just that film festival in either storefronts near the theaters or in hotels. Sundance Luxury Lounges are high-end retailers who have special one-on-one shopping for celebrities. Some of the items are swag, meaning that it is free to celebrities in the hopes that the celebrities will be photographed wearing the product, creating demand both at Sundance and after the festival. Magazines such as InStyle run daily columns on who was seen, with whom, where and wearing what. All of the hype creates an environment for high-end luxury goods sales both at Sundance and at retailers world-wide. The focus on celebrities is not without detractors who dislike the spotlight shifting from solely on the independent films to include the celebrities. While movie stars create media coverage, the long run sustainability of the festival is on the quality of films presented year after year.

On the surface, the Roswell UFO Festival does not remotely compete with the other two special events highlighted in this study. Of course, several people would still ski or snowboard at a Park City resort or travel to the Mount Rushmore and the Black Hills without the film festival or motorcycle event. Few tourists would travel to Roswell if not for the curiosity of association with aliens. During the UFO Festival and throughout the rest of the year, Roswell is a brief stopping point for a person traveling in the region because the city is branded as an extraterrestrial hot spot. Without the alien association, Roswell would be no different than several other small to mid-sized cities in the southwest. In addition, visiting Roswell and the UFO Festival is not a special event that easily leads to repeat visitors on an annual basis. Once a tourist visits Roswell and reviews the UFO crash site information, there is little reason to return the next year. The special events in Sturgis and Park City are more conducive to repeat visitors based on the multiple riding paths and the unique mountain location of the Motorcycle Rally and the new movies offered each year at the Sundance Film Festival. This is the growth potential of the Roswell UFO Festival. The Festival began in 1996, well after the fascination with UFO's began. The X-Files television show began in 1993 and moved aliens from science fiction to mainstream entertainment. The 1999-2003 Roswell television show further engrained the idea of aliens living as humans. While alien curiosity is more mainstream now, it is still not at the level of bikers and movies. To grow the economic impact of the festival, there has to be more reasons for repeat attendance and retail shopping.

The final information offered in Table 1 focus on city tax revenue. Roswell is the biggest city in the study and earns the highest tax revenue at $\$ 17.5$ million per year, followed by Park City at $\$ 6.8$ million, and Sturgis at $\$ 2.8$ million. The relative importance of the three special events is estimated by dividing dollar value of each event by the annual city tax revenue. Without question, the Sturgis Motorcycle Rally is critical to the economic viability of Sturgis and the surrounding area. With only \$2.8 million in annual tax revenue, the event dollar impact of \$132 million yields a ratio of 47.14. The Park City average dollar value as a percent of sales tax revenue is a significant 8.82. The Park City event is not comparable to Sturgis but the $800 \%$ value relative to city sales tax indicates the Sundance Film Festival is very important to the economic development of the region. The Roswell UFO Festival is shown to be a relative minor event for the overall economic development base of the city. The 0.07 estimated dollar value as a percent of annual sales tax revenue implies the UFO Festival might be a branding tool that keeps the city of Roswell's name in the media and popular culture in addition to creating a modest positive economic impact.

Festivals and special events are a way for cities to create an identity, especially in comparison to other cities nearby. In this context, differences between the festival cities and a comparison city are noticeable. Spearfish, South Dakota is less than 20 miles from Sturgis on Interstate 90 and lies at the other end of Highway 14A. It could easily be the site of the Rally. While both cities had a growth in household income of around $15 \%$, Sturgis's median household income is $12 \%$ higher than Spearfish's median household income is. This is surprising given that homes in Sturgis are about 20\% cheaper than in Spearfish. The rate of home price appreciation is basically the same in comparison time period. While Sturgis's population fell slightly from 2000 to 2007, the population of Spearfish rose $13.8 \%$. One reason for the population gains for Spearfish is that it is viewed as a nicer city than Sturgis. 
Because of the retail sales during the Rally, the prices for retail space in downtown Sturgis has skyrocketed. Many of the storefronts have been purchased by outside vendors and are empty except during the two-weeks for the Rally. Everyday businesses must close and move everything out of the stores for the two weeks. Additionally, the close proximity of Rapid City also causes a limited retail presence in Sturgis. Comparatively, Spearfish is located farther from Rapid City, making a daily trip for groceries or sundries inconvenient. While Sturgis has sacrificed some aspects of a community, the Rally is the lifeblood of the town and of the entire northern Black Hills.

Park City does not have as easy of a competitor city to identify. There are several other cities with major ski resorts such as Provo and Ogden all within an hour's drive of Salt Lake City and the airport. Both Provo and Ogden are located on Interstates and don't require driving through the mountains to reach. World-class skiing and snowboarding are both available. However, Park City's isolation lends itself to the mystique of a luxury festival. Limited access allows for security and better control of attendees. While Sturgis's goal is as many people as possible, Park City doesn't want to mainstream the film festival but rather have fewer attendees from the film industry including celebrities covered by the media. The Sundance Film Festival also brands Park City as the ski resort for the stars, which increases visitors throughout the rest of the year who are looking to ski where celebrities and Olympians ski. Correspondingly, home values and income in Park City are higher than for all of the other cities and areas nearby. Income averages $\$ 20,000$ a year more and houses average $\$ 200,000$ more in Park City than in the surrounding area.

Roswell is located in a fairly isolated part of the southwest. The nearest airport is over 200 miles away in El Paso, Texas. Visitors to Roswell have to make a commitment to travel there. However, the alien brand does provide Roswell with name recognition. The closest competitor city is Ruidoso, New Mexico, 75 miles away. Ruidoso is located in the southern Rocky Mountains and boasts ski resorts, horse racing and gambling on the Mescalero Indian Reservation. Ruidoso is a resort town and its median household income is above the state average while Roswell's median household income is below the state average. While Roswell does not have the draws of Ruidoso, Roswell's notoriety provides it with a secondary economic impact from visitors to Ruidoso much like the impact of the Sturgis Motorcycle Rally on Devil's Tower in Wyoming. Visitors to Ruidoso can drive out for an afternoon excursion to Roswell while travelers to and from Ruidoso coming from Texas in the east can stop for gas and to eat before heading into the mountains. Additionally, Roswell is the last major city heading east until well in Texas.

\section{CONCLUSION}

This study compares the economic impact of the Sturgis Motorcycle Rally, Roswell UFO Festival, and the Sundance Film Festival in Park City. The results imply that the three events are clearly different with respect to economic impact and magnitude of the economic impact. Specifically, the Sturgis Motorcycle Rally dominates in number of event participants at over 400,000 per year and dollar valuation at over $\$ 130$ million per year. The Sturgis Motorcycle is an integral part of the community and the successful continuation of the event is integral to the economic health of the city and surrounding region. With an annual attendance of almost 50,000 and a dollar valuation of $\$ 60,000$, the Sundance Film Festival in Park City appears to be a contributing factor to the city's success. Population growth, median household income growth, median home value growth, and average expenditure per participant are greater in Park City than the other two cities in the study. The positive economic data implies there is potential for continued growth for Park City and the Sundance Film Festival. The UFO Festival and Roswell are a distant third in relative economic impact of the special event. Annual UFO Festival participation is 10,000 people and the dollar valuation of the event is approximately $\$ 1.25$ million. The Roswell special event is not critical to the economic health of the city but does provide a positive return and helps the city maintain a national and international identity as a leading location surrounding the alien visitation question.

Repeat attendees are important to the continued success the Sturgis Motorcycle Rally and Sundance Film Festival. Sturgis's approach is to provide a low-cost and fun entertainment venue while Park City provides unique entertainment with the combination of independent films and skiing with celebrities. Roswell has yet to determine how to create the environment for repeat attendees. Possible additions would be concerts such as have been added to Sturgis or celebrity draws beyond the alien abduction theme. Roswell's isolated location and no natural scenery are another factor inhibiting the growth the festival. While the impact differs among the three cities, the festivals are 
integral to the identity of each community both within itself and with the rest of the world. This reinforces the social value of these events. Avenues for future research include a more explicit estimation of the economic impact data, a comparison of the Sturgis Motorcycle Rally to comparable biker events in alternate locations (e.g., Daytona Beach and Laconia), and a time-series approach evaluating the growth of the Sundance Film Festival in Park City.

\section{AUTHOR INFORMATION}

Dr. Neil Terry is dean and professor of economics at West Texas A\&M University in Canyon, Texas. Dr. Terry earned a doctorate degree in economics from Texas Tech University.

Dr. Anne Macy is the Gene Edwards Professor of Finance at West Texas A\&M University in Canyon, Texas. Dr. Macy earned a doctorate degree in economics from Texas Tech University.

Dr. James Owens is department head and professor of finance at West Texas A\&M University in Canyon, Texas. Dr. Owens earned a doctorate degree in finance from Harvard University.

\section{REFERENCES}

1. Besculides, A., M. Lee, \& P. McCormic (2002). Resident's perceptions of the cultural benefits of tourism. Annals of Tourism Research, 29(2), 303-319.

2. Berlitz, C. \& W. Moore (1980). The Roswell Incident. New York: Grosset \& Dunlap.

3. Chwe, M. (1998). Culture, circles and commercials: Publicity, common knowledge and social coordination. Rationality and Society, 10(1), 47-75.

4. Crompton, J. \& S. McKay (1997). Motives of visitors attending festival events. Annals of Tourism Research, 24(2), 425-439.

5. Formica, S. \& S. Murrmann (1998). The effects of group membership and motivation on attendance: An international festival case. Tourism Analysis, 3(3), 197-207.

6. Getz, D. (1994). Residents' attitudes toward tourism: A longitudinal study in Spey Valley, Scotland. Tourism Management, 15(4), 247-258.

7. Getz, D. (1997). Event management and event tourism. Cognizant Communication, New York.

8. Gursoy, D., K. Kim, \& M. Uysal (2004). Perceived impacts of festivals and special events by organizers: An extension and validation. Tourism Management, 25(2), 171-181.

9. Jeong, G., \& B. Faulkner (1996). Resident perceptions of mega-event impacts: The Taejon International Exposition case. Festival Management \& Event Tourism, 4(1), 3-11.

10. Keogh, B. (1990). Resident and recreationists' perceptions and attitudes with respect to tourism development. Journal of Applied Recreation Research, 15(2), 71-83.

11. Madrigal, R. (1993). A tale of tourism in two cities. Annals of Tourism Research, 20(2), 336-353.

12. Meehan, E. (2008). Tourism, development, and media. Society, 45(4), 338-341.

13. Nicholson, R. \& D. Pearce (2001). Why do people attend events: A comparative analysis of visitor motivations at four south island events? Journal of Travel Research, 39(1), 449-460.

14. Paradis, T. (2002). The political economy of theme development in small urban places: The case of Roswell, New Mexico. Tourism Geographies, 4(1), 22-43.

15. Rao, V. (2001). Celebrations as social investments: Festival expenditures, unit price variation and social status in rural India. The Journal of Development Studies, 38(1), 71-97.

16. Scott, D. (1996). A comparison of visitor's motivation to attend three urban festivals. Festival Management \& Event Tourism, 3(3), 121-128.

17. Thrane, C. (2002). Jazz festival visitors and their expenditures: Linking spending patterns to musical interest. Journal of Travel Research, 40(1), 281-286.

18. Tosun, C. (2002). Host perceptions of impacts: A comparative tourism study. Annals of Tourism Research, 29(1), 231-245.

19. Uysal, G. \& M. Gitelson (1994). Assessment of economic impacts: Festivals and special events. Festival Management \& Event Tourism, 2(1), 3-10.

20. Walo, M., A. Bull \& H. Green (1996). Achieving economic benefits at local events: A case study of a local sport event. Festival Management \& Event Tourism, 3(3), 96-106. 